\title{
EFEKTIVITAS MODEL PEMBELAJARAN GROUP INVESTIGATION TERHADAP KEMAMPUAN MENULIS TEKS ANEKDOT PADA SISWA KELAS X SMK SULTAN ISKANDAR MUDA MEDAN TAHUN PELAJARAN 2018/2019
}

\author{
Ebenezer Gultom $^{1}$, Sri Dinanta Beru Ginting ${ }^{2}$, Oktaviandi Bertua Pardede ${ }^{3}$ \\ Universitas Prima Indonesia ${ }^{1}$, Universitas Prima Indonesia ${ }^{2}$, Universitas Prima Indonesia ${ }^{3}$ \\ Pos-el: gultomeben62@gmail.com ${ }^{1}$, sridinantaginting@ unprimdn.ac.id ${ }^{2}$, \\ andie_pard@yahoo.com ${ }^{3}$
}

\begin{abstract}
ABSTRAK
Penelitian ini bertujuan untuk mengetahui masalah pada siswa dalam kemampuan menulis teks anekdot yang masih sangat rendah, beberapa faktor penyebabnya adalah penggungaan model pembelajaran yang kurang tepat. Penelitian dilakukan untuk mengetahui efektivitas model pembelajaran group investigation terhadap kemampuan menulis teks anekdot siswa kelas X SMK Sultan Iskandar Muda Medan tahun pelajaran 2018/2019. Untuk dilasanakan penelitian ini sampel terlebih dahulu diambil dari kelas X-MM1 dan X-MM2 yang berjumlah 62 siswa. Sebagai alat pengumpulan data dalam penelitian ini digunakan tes pilihan berganda sebagai alat pengumpul data. Hipotesis dalam penelitian ini adalah hasil belajar menulis teks anekdot dengan menggunakan model pembelajaran group investigation lebih baik dari pada hasil belajar dengan menggunakan model ceramah. Data penelitian ini dianalisis dengan menggunakan rumus uji " $t$ " karena demikian $t_{\text {tabel }} 2,00<t_{\text {hitung }} 7,2>t_{\text {tabel }} 2,00$. Maka, hipotesis nol $\left(H_{0}\right)$ ditolak dan hipotesis $\left(H_{a}\right)$ diterima. Berdasarkan analisis data maka dapat disimpulkan bahwa terdapat efektivitas yang signifikan atas penggunaan model group investigation terhadapt kemampuan menulis teks anekdot pada siswa kelas X SMK Sultan Iskandar Muda Medan Tahun Pelajaran 2018/2019.
\end{abstract}

Kata Kunci: Group Investigation, Menulis, Teks Anekdot.

\begin{abstract}
In this research the writer found that students writing skill low. So, this research aimed to know what the students problems are. One of the problems is the usage of learning method is not appropriate. The objective of the research was to find out whether group investigation affect the students writing skill in writing anecdote text on tenth grade of SMK Sultan Iskandar Muda in Academic year 2018/2019. The sample of this research were X-MM-1 and X-MM-2 that consist of 62 students. The instrument for collecting data was multiple choice test, the hypothesis of this research is the student score that were taught by using group investigation were higher than the students score that were taught with out group investigtion. The data was analized by using $t$-test the result of this research is $t$-table 2,00<t-observed 7,2 $>t$-table 2,00. It means that $H_{a}$ hypothesis was accepted. So, based on the research it can be concluze that there a significant effect of using group investigation method in writing anecdote text on tenth grade of SMK Sultan Iskandar Muda in academic year 2018/2019.
\end{abstract}

Keywords: Group Investigation, Writing, Anecdote Text. 


\section{PENDAHULUAN}

Secara umum Bahasa Indonesia adalah salah satu bidang studi yang diajarkan di setiap sekolah. Bahasa Indonesia merupakan Bahasa Nasional yang mampu dipergunakan dengan baik dan benar oleh masyarakat Indonesia, Bahasa Indonesia adalah salah satu mata pelajaran yang diujikan saat ujian nasional dan merupakan salah satu syarat kelulusan bagi sekolah.

Dalam bahasa Indonesia dikenal adanya empat aspek keterampilan berbahasa yang harus dimiliki oleh siswa antara lain: menyimak, berbicara, membaca, dan menulis. Menyimak dan membaca merupakan keterampilan yang bersifat reseptif sedangkan berbicara dan menulis tergolong dalam keterampilan yang bersifat produktif dan ke empat keterampilan berbahasa itu saling berhubungan yang sangat erat meskipun masing-masing memiliki ciri tertentu. Menurut Dalman "menulis merupakan suatu kegiatan komunikasi berupa penyampain pesan (informasi) secara tertulis kepada pihak lain dengan menggunakan bahasa tulis sebagai alat atau medianya. Aktivitas menulis melibatkan beberapa unsur yaitu: penulisan sebagai penyampaian pesan, isi tulisan, saluran atau media, dan pembaca".

Menurut Dawson (Tarigan 2005:1) menyatakan bahwa 'dalam memperoleh keterampilan berbahasa maka biasanyakita melalui tahap yang teratur dengan diawali pada masa kecil, kita belajar menyimak atau mendengarkan setelah itu berbicara setelah itu kita belajar membaca dan menulis, menyimak dan berbicara dipelajari kita sebelum memasuki sekolah sedangkan membaca dan menulis dipelajari kita di sekolah. Keempat keterampilan tersebut pada dasarnya merupakan satu kesatuan'.

Melihat permasalahan yang terjadi pada pembelajaran teks anekdot di kelas X SMK Sultan Iskandar Muda
Medan, penulis merasa tertarik untuk melakukan suatu penelitian. Penelitian ini dilakukan sebagai alternatif pemecahan masalah yang dihadapi siswa dalam pembelajaran teks anekdot. Maka peneliti menentukan judul "Efektivitas Model Group Investigation Terhadap Kemampuan Menulis Teks anekdot Pada Siswa Kelas X SMK Sultan Iskandar Muda Medan Tahun Pelajaran 2018/2019".

\section{METODE PENELITIAN}

Metode penelitian mempunyai peranan yang sangat penting dalam suatu penelitian.

Berhasil atau tidaknya seseorang di dalam melakukan penelitian akan ditentukan melalui metode yang digunakan. Metode yang dipakai dalam suatu penelitian merupakan suatu alat untuk membantu seseorang dalam membuktikan kebenaran akan hipotesis yang ditentukannya dan juga membantu dalam menyelesaikan masaalah yang ada dalam penelitian tersebut.

\section{Menurut Arikunto (2006:12)} menyatakan "desain atau rancangan penelitian dapat dikatakan alur pengumpulan data eksperimen pembelajaran yang dilaksanakan di dalam kelas berdasarkan penelitiannya." Oleh sebab itu eksperimen penelitian ini menggunakan two group posstes only yaitu rancangan ini terdiri atas dua kelompok yang keduanya ditentukan secara acak, pada kelompok pertama disebut kelas eksperimen yang diberikan perlakuan sedangkan kelompok kedua disebut kelas kontrol tanpa adanya perlakuan.

\section{HASIL DAN PEMBAHASAN Hasil Penelitian dan Pembahasan}

Tabel 4.3 Distribusi Data Kemampuan Menulis Teks Anekdot Siswa di Kelas Kontrol Tanpa Perlakuan

\begin{tabular}{|c|c|c|c|c|c|}
\hline $\begin{array}{c}\text { Selang } \\
\text { Nilai }\end{array}$ & $\mathrm{Fi}$ & $\mathrm{Xi}$ & $\mathrm{FiXi}$ & $\mathrm{Xi} 2$ & $\mathrm{Fi}(\mathrm{Xi}) 2$ \\
\hline
\end{tabular}




\begin{tabular}{|c|c|c|c|r|c|}
$445-49$ & 3 & 47 & 141 & 2209 & 6627 \\
\hline $50-54$ & 0 & 0 & 0 & 0 & 0 \\
\hline $55-59$ & 4 & 57 & 228 & 3249 & 12996 \\
\hline $60-64$ & 6 & 62 & 372 & 3844 & 23064 \\
\hline $65-69$ & 5 & 67 & 335 & 4489 & 22445 \\
\hline $70-74$ & 8 & 72 & 576 & 5184 & 41472 \\
\hline $75-79$ & 5 & 77 & 385 & 5929 & 29645 \\
\hline & 31 & 382 & 2037 & 24904 & 136249 \\
\hline
\end{tabular}

Berdasarkan tabel di atas dilakukan perhitungan yang dimulai dari menyusun daftar distribusi frekuensi. Namun, sebelum menyusun daftar distribusi frekuensi terlebih dahulu mencari nilai rata-rata dan simpangan baku. Adapun nilai rata-rata kelas kontrol yakni 65,70 dan simpangan baku yaitu 8,94. Berdasarkan kriteria pengujian yaitu menerima sampel.

Tabel 4.5 Distribusi Data Kemampuan Menulis Teks Anekdot Kelas Eksperimen dengan Model Group Investigation

\begin{tabular}{|c|c|c|c|c|c|}
\hline $\begin{array}{c}\text { Selang } \\
\text { Nilai }\end{array}$ & $\mathrm{Fi}$ & $\mathrm{Xi}$ & $\mathrm{FiXi}$ & $\mathrm{Xi2}$ & $\mathrm{Fi}(\mathrm{Xi}) 2$ \\
\hline $50-56$ & 2 & 53 & 106 & 2809 & 5618 \\
\hline $57-63$ & 4 & 60 & 240 & 3600 & 14400 \\
\hline $64-70$ & 8 & 67 & 536 & 4489 & 35912 \\
\hline $71-77$ & 11 & 74 & 814 & 5476 & 60236 \\
\hline $78-84$ & 4 & 81 & 324 & 6561 & 26244 \\
\hline $85-91$ & 2 & 88 & 176 & 7744 & 15488 \\
\hline \multicolumn{5}{|c|}{ Berdasarkan tabel di atas } \\
\hline
\end{tabular}

dilakukan perhitungan yang dimulai dari menyusun daftar distribusi frekuensi. Namun, sebelum menyusun daftar distribusi frekuensi terlebih dahulu mencari nilai rata-rata dan simpangan baku. Adapun nilai rata-rata kelas eksperimen yakni $70,83 \%$ dan simpangan baku yaitu 8,82 .

\section{Tabel 4.7 Uji Normalitas Data dengan Uji Liliefors}

berasal dari populasi berdistribusi normal jika $\mathrm{L}_{\text {hitung }}<\mathrm{L}_{\text {tabel }}$ dan untuk menolak kriteria pengujian jika syarat tidak dipenuhi. Berdasarkan tabel harga $\mathrm{L}_{\text {hitung }}<\mathrm{L}_{\text {tabel }}$ ini berarti menerima kriteria.

\section{Tabel 4.8 Uji Homogenitas}

\begin{tabular}{|c|c|c|c|c|}
\hline Data & Varians & F $_{\text {hitung }}$ & F $_{\text {tabel }}$ & $\begin{array}{c}\text { Kesimpu } \\
\text { lan }\end{array}$ \\
\cline { 1 - 2 } $\begin{array}{c}\text { Posttest } \\
\text { Kontrol }\end{array}$ & 79,94 & & & \\
\cline { 1 - 2 } $\begin{array}{c}\text { Posttest } \\
\text { Eksperimen }\end{array}$ & 77,87 & 1,02 & 1.84 & $\begin{array}{c}\text { Homoge } \\
\text { n }\end{array}$ \\
\hline
\end{tabular}

\begin{tabular}{|c|c|c|c|c|c|}
\hline $\begin{array}{l}\mathbf{N} \\
\mathbf{0}\end{array}$ & Data & Kelas & Lo & $\begin{array}{c}\text { Ltabe } \\
\text { l }\end{array}$ & $\underset{n}{\text { Kesimpula }}$ \\
\hline 1 & $\begin{array}{c}\text { Posstes } \\
\text { t }\end{array}$ & Kontrol & $\begin{array}{c}0,15 \\
4\end{array}$ & 0,16 & Normal \\
\hline 2 & $\begin{array}{c}\text { Posttes } \\
t\end{array}$ & $\begin{array}{c}\text { Eksperime } \\
n\end{array}$ & $\begin{array}{c}0,12 \\
5\end{array}$ & 0,16 & Normal \\
\hline
\end{tabular}

Berdasarkan tabel di atas data posttest untuk kedua sampel diperoleh $F_{\text {hitung }}<\mathrm{F}_{\text {tabel }}$ maka diterima $\mathrm{H}_{0}$ bahwa sampel memiliki varians yang homogen. Jika sebaliknya maka, varians tidak homogen.

\begin{tabular}{|c|c|c|c|c|}
\multicolumn{1}{c}{} & Tabel 4.9 Uji Hipotesis \\
\hline Data & $\begin{array}{c}\text { Nilai } \\
\text { rata- } \\
\text { rata }\end{array}$ & $\mathbf{t}_{\text {hitung }}$ & $\mathbf{t}_{\text {tabel }}$ & Kesimpulan \\
\hline $\begin{array}{c}\text { Posttest } \\
\text { Kontrol }\end{array}$ & $\mathbf{6 5 , 7 0}$ & \multirow{2,2}{2,00}{} & $\begin{array}{c}\text { Ada } \\
\text { pengaruh } \\
\text { yang } \\
\text { signifikan }\end{array}$ \\
\hline $\begin{array}{c}\text { Posttest } \\
\text { Eksperimen }\end{array}$ & $\mathbf{7 0 , 8 3}$ & $\mathbf{2 , 2}$ & \\
\hline
\end{tabular}

Berdasarkan data hasil peneltian kelas kontrol dan eksperimen diperoleh nilai rata-rata kelas kontrol 65,70 dan kelas eksperimen diperoleh nilai ratarata 70,83. Berdasarkan data hasil perhitungan diperoleh $t_{\text {hitung }}=7,2$. $t_{\text {tabel }}$ $=2,00$ maka, kriteria pengujian hipotesis penelitian ini adalah thitung $>t_{\text {tabel, }}$ Hipotesis nilai $\mathrm{H}_{0}$ ditolak dan hipotesis alternative $\left(\mathrm{H}_{\mathrm{a}}\right)$ diterima. Hal ini membuktikan bahwa terdapat perbedaan yang signifikan antara kelas kontrol dan kelas eksperimen. Hal ini membuktikan bahwah model Group Investigation berpengaruh positif terhadap kemampuan menulis teks anekdot siswa kelas X SMK Sultan Iskandar Muda Medan Tahun Pelajaran 2018/2019. 


\section{SIMPULAN}

Berdasarkan hasil penelitian yang telah dijelaskan pada bab sebelumnya, maka dapat disimpulkan bahwa pembelajaran model Group Investigation dapat digunakan untuk proses pembelajaran kemampuan menulis teks anekdot siswa kelas X SMK Sultan Iskandar Muda Medan. Efektivitas hasil penelitian ini telah disimpulan sebagai berikut.

Tingkat kemampuan siswa kelas X SMK Sultan Iskandar Muda Tahun Pelajaran 2018/2019 dalam menulis teks anekdot dengan tanpa adanya perlakuan dapat dikategorikan cukup dengan nilai rata-rata 60,82 .

Tingkat kemampuan siswa kelas X SMK Sultan Iskandar Muda Tahun Pelajaran 2018/2019 dalam menulis teks anekdot dengan menggunakan model Group Investigation dapat dikategorikan baik dengan nilai rata-rata 70,69.

Penggunaan model Group Investigation memiliki efektivitas yang signifikan terhadap kemampuan menulis teks anekdot daripada tidak menggunakan perlakuan pada siswa kelas X SMK Sultan Iskandar Muda Medan Tahun Pelajaran 2018/2019. Hal ini dibuktikan dari hasil perbandingan nilai rata-rata antara dengan menggunakan model Group Investigation dengan yang tidak adanya perlakauan yakni, nilai rata-rata kelas eksperimen 70,69 sedangkan nilai ratarata kelas kontrol 60,82. Selain itu, dapat juga dilihat dari hasil uji " $\mathrm{t}$ " diperoleh $t_{\text {hitung }}>\mathrm{t}_{\text {tabel }}$ yaitu $4,42>2,00$. Maka hipotesis nol $\left(\mathrm{H}_{0}\right)$ ditolak dan Hipotesis alternatif $\left(\mathrm{H}_{\mathrm{a}}\right)$ diterima.

\section{DAFTAR PUSTAKA}

Arikunto. 2016. Prosedur Penelitian Suatu Pendekatan Praktek. Jakarta: PT. Gramedia.

Dalman. 2015. Keterampilan Menulis. Jakarta: PT Raja Grafindo Persada.
Hamdani. 2017. Startegi Belajar Mengajar. Bandung: Pustaka Setia.

Istarani. 2011. Model Pembelajaran Inovatif. Medan: Iscom.

Kosasih. 2017. Jenis-Jenis teks. Bandung: Yrama Widya Margahayu Permai.

Keraf, Goris. 2005. Argumentasi dan Narasi. Jakarta: PT Gramedia.

Medyasari, dkk. 2017. Jurnal. "Efektifitas Model Pembelajaran Group Investigation Berbantuan Kartu Soal Terhadap Prestasi Belajar Ditinjau Dari Motivasi Belajar Pada Materi Turunan Fungsi Aljabar Pada Kelas XI SMA Negeri 5 Semarang." Fakultas Keguruan dan Ilmu Pendidikan.

Novirin. 2014. Jurnal. "Efektivitas Penerapan Metode Group Investigation Dalam Peningkatan Kemampuan Berpikir Tingkat Tinggi dan Prestasi Belajar Peserta Didik Kelas X SMK PGRI 2 Prabumulih." Fakultas Keguruan dan Ilmu Pendidikan.

Semi. 2017. Dasar-dasar Keterampilan Menulis. Bandung: Angkasa.

Taringan, Henry Guntur. 2008. Menulis Sebagai Suatu Keterampilan Berbahasa. Bandung: Angkasa.

Trianingsih. 2018. Jurnal. "Efektivitas Penerapan Model Group Investigation Terhadap Kemahiran Menceritakan Kembali Isi Cerita Fabel Siswa Kelas VII SMP Negeri 13 Satap Tanjungpinang." Fakultas

Keguruan dan Ilmu Pendidikan.

Sugiyono.2017. Metode Penelitian Pendidikan. Bandung: Alfabeta.

Sudjana. 2005. Metoda Statistika. Bandung: Tarsito.

Yumisnaini. 2013. "Efektivitas Metode Group Investigation Terhadap Keterampilan Menulis Artikel pada Kelas XI SMA Negeri 1 Pancurbatu". Skripsi: Fakultas 
Keguruan dan Ilmu Pendidikan.

Yulitha, Ika. 2016. "Pengaruh Model

Pembelajaran Group

Investigation Terhadap Motivasi

Belajar pada siswa Kelas VII

SMP Negeri 1 Tanngamus".

Skripsi: Fakultas Keguruan dan

Ilmu Pendidikan. 